\title{
Undergraduate students who are required to withdraw from university: the role of ethnicity
}

Ruth Woodfield

School of Management

University of St Andrews

KY169RJ

Email: rw57@st-andrews.ac.uk

\begin{abstract}
A large body of international research focuses on identifying reasons why students do not 'persist' (Tinto 2007) within higher education. Little research has focused on students whose leaving is non-voluntary and where narratives of 'persistence' are therefore not as pertinent. This article seeks to refocus some of the attention onto the distinct group of students who do not elect to leave their studies but who are, instead, required to withdraw; in English higher education, such students leave under 'Academic Fail' and 'Exclusion' categories. More specifically, it explores the relationship between student leavers' ethnicity and their likelihood of being required to withdraw. Utilising a large dataset comprising UK-domiciled undergraduate students enrolled to take a degree within an English HEI in 2010-11, it finds that most groups of Black and Minority Ethnic (BME) students are more likely to be required to withdraw than White students. Ethnicity exerts an independent impact on a student's likelihood of being required to withdraw, when other background and on-course characteristics are controlled for, but this impact varies by disciplinary area. It is suggested that these findings implicate factors within the HE sector itself as key drivers in the process that leads to students being
\end{abstract}


required to withdraw. Lessons are drawn out for those tasked with managing the student experience within higher education.

Key words: Higher education, non-voluntary withdrawal, ethnicity, discipline

\section{Introduction and background}

A growing body of international research indicates that students from diverse backgrounds participate, persist and attain in Higher Education (HE) at different rates, and that such differences can be explained with reference to a range of students' background characteristics, as well as practices within HE itself. Several background and on-course characteristics have been identified as heightening the general vulnerability of students to not completing their courses. These include being: a man; from a lower socio-economic class; a mature student; a part-time student; a student attending a more local higher education institution (HEI); being from a Black and Minority Ethnic (BME) background (Hofman \& van den Berg 2003; Christie, Munro \& Fisher 2004; Scott \& Smart 2005; Carter 2006; Engle \& Tinto 2008; Tinto 2007; ECU/HEA 2008; Tumen, Shulruf \& Hattie 2008; Severiens \& Wolff 2008; Meeuwisse, Severiens \& Born 2010; HEA 2011; Richardson 2008, 2015; Stevenson 2012; Thomas 2012; Woodfield 2014).

Tinto's corpus on student retention, based largely on the US system and data, has made a very significant contribution to academic and policy debates. It has also, however, led to the development of a dominant focus on student 'persistence' (Tinto 2007). Very little research has focused on students whose leaving is non-voluntary and where the narrative of 'persistence' is therefore not as pertinent as it is in relation to other categories of leaving. This article seeks to address this gap in the literature. It is based upon analysis of a dataset comprising all UK-domiciled students registered to study for a single- 
discipline $^{1}$, undergraduate degree within any English ${ }^{2}$ higher education institution in the years $2010 / 11$, and centres on the question of which factors predict the likelihood that student leavers will be required to withdraw rather than withdraw voluntarily, and whether, in particular, the ethnic background of leavers plays a part in influencing their likelihood of being required to withdraw rather than withdrawing voluntarily.

While the overwhelming majority ( $94 \%$ - see Woodfield 2014) of undergraduate students in England go on to complete their courses, and receive their degree qualification, a minority of them does not. When students withdraw, the event is reported to a central register by their institutions, and, where known, a 'reason for leaving' category is assigned to their case for monitoring and reporting purposes. Students most commonly withdraw under the reason categories of 'Academic fail/Progress disallowed' and 'Other Personal'. The former category accounts for the largest group of non-voluntary withdrawals. A smaller group of non-voluntary leavers are withdrawn under the 'Exclusion' category. Together, 'Academic fail/Progress disallowed', and 'Exclusion' account for all students whose withdrawal can be categorised as explicitly non-voluntary, and, for the purposes of this article, comprise a sub-group of leavers who are 'required to withdraw'. While students who are required to withdraw account for approximately only $2 \%$ per annum of all students within English HEIs, a case is nonetheless made here for more careful examination of this comparatively unusual, yet non-trivial, phenomenon.

\footnotetext{
1 Students who undertook joint degrees (approximately 15\%) were excluded or the purposes of analysis because the data provided no indication of the primary discipline that such students were aligned to, and 'housed' within; in the context of this article such information was required in order to explore the disciplinary differences that can occur in relation to non-voluntary withdrawal patterns.

${ }^{2}$ Although ethnicity data are available on all UK students, only English students were included in this analysis as the percentages of BME students within Scotland, Northern Ireland and Wales remain comparatively small; for example, $97 \%$ of students reporting as 'Black', were studying in English universities. English students account for approximately $84 \%$ of UK higher education students (XXX).
} 
This is the first academic article to focus upon those students who are required to withdraw, and the first to explore the relationship between ethnicity and the likelihood of being required to withdraw. The focus upon student ethnicity in relation to nonvoluntary withdrawal emerges from the context of national evidence linking ethnic minority status to a greater likelihood of non-voluntary withdrawal from primary and secondary education, and from international evidence linking ethnic minority status to a greater general likelihood of withdrawal from HE.

National evidence from primary and secondary education levels indicates that some BME groups are significantly more likely to be excluded from school than White pupils (Runnymede Trust 2002; EHRC 2010, 2015; DofE 2012; Office of the Children's Commissioner 2012); part of the rationale for this exploration, therefore, was to assess whether the same observable trend can be identified within tertiary education.

The role played by ethnicity in HE is perhaps among the least understood nationally and internationally, despite the burgeoning literature on student progress. It is important to note that the available international evidence should not be treated as homogenous due to the contingent nature of ethnicity category definitions across geographical regions (Morning 2008). It is also the case that there is wide variation in practice across countries specifically in relation to the collection of student data related to ethnic identification (Richardson 2008), with many countries collecting no data on students' ethnicity (Meeuwisse et al. 2010; European Commission/EACEA/Eurydice 2014). It is nevertheless the case, however, that, where international evidence does exist relating to the relationship between ethnicity and withdrawal from HE studies, the majority of such evidence suggests that ethnic minority status is associated with a greater likelihood of withdrawal. This finding has, for instance, been identified in the US (Eimers \& Pike 
1997; Hobson-Horton \& Owens 2004; Carter 2006; Engle \& Tinto 2008), New Zealand (Scott \& Smart 2005; Ministry of Education, New Zealand 2015), the Netherlands (Hofman \& van den Berg 2003; Wolff \& Pasztor 2008; Meeuwisse, Severiens \& Born 2010) and the UK (ECU/HEA 2008; Stevenson 2012; Thomas 2012; Richardson 2008, 2015; Woodfield 2014).

The available evidence suggests that, even in regions where students' ethnicity information is collected, as is the case in the UK, the extent to which it is analysed and effectively utilised by institutions to help them understand and manage trends in retention and attainment of students from BME backgrounds, varies significantly (Van Dyke \& Gunaratnam 2000; Jacobs, Owen, Sergeant \& Schostak 2007; ECU/HEA 2008; Richardson 2008; Meeuwisse et al. 2010). It is hoped that the findings of this article serve to highlight important issues for HEI staff and managers relating to the nature of the 'student experience' offered to students, and whether this is as inclusive as it might be.

\section{Literature Review}

The overwhelming majority of research focusing on retention in HE concentrates on students whose withdrawal is formally defined as 'voluntary', or at the very least has a tendency to conflate students whose withdrawal is non-voluntary within a general category of those who do not 'persist' (Tinto 2007; see also Berger \& Braxton 1998; Wilcox, Winn \& Fyvie-Gauld 2005; Bozik 2007; Severiens \& Wolff 2008; Roberts 2012; Thomas 2012). Such research draws out the extent to which 'voluntary' withdrawal may nonetheless result from a range of pressures that act as significant push and pull factors in relation to student decision-making about staying on, or leaving, their course; these 
include debt, employment and family commitments. It is also undoubtedly the case that many students withdrawing 'voluntarily' under some 'reason for leaving' categories, such as 'Other personal' or 'Other', may in fact be withdrawing for reasons that are partially or primarily associated with difficulties with their studies; they may be struggling academically or experiencing challenges engaging with staff and fellow students. Notwithstanding these riders, it is suggested here that students who do leave under the categories associated with 'voluntary' withdrawal - e.g. 'Finance'; 'Other personal'; 'Left for employment' - are qualitatively different from those whose withdrawal is more explicitly 'non-voluntary'; those whose withdrawal is assigned to the 'reason for leaving' categories of 'Academic fail/Progress disallowed' or 'Exclusion'.

Although there is a striking lack of research focusing directly on students who are required to withdraw due to academic failure, some groups of students have been identified as being more likely to experience academic difficulties in relation to their studies and/or less likely to achieve a 'Good degree's. These notably include students from the more disadvantaged socio-economic backgrounds and students belonging to particular minority ethnic groups (Broecke and Nicholls 2007; Jacobs et al. 2007; ECU/HEA 2008; Richardson 2008; Thiele et al. 2014; Thomas 2012; Cotton 2015). The trend for students from BME backgrounds to achieve lower degrees is a consistently identified one in the literature and much of this evidence has an obvious pertinence for exploring the relationship between ethnicity and the requirement to withdraw due to academic failure. It has, for instance, been noted that ethnic minority status often intersects with, and is mediated by, other background and on-course characteristics to

\footnotetext{
${ }^{3}$ The term 'Good degree', also referred to as an 'Upper degree', is used within academic and policy literature to indicate a UK degree classified within the top two classifications: either 'Upper Second' (normally associated with an overall achievement of a mean mark between 60-69\%) or 'First' (normally associated with an overall achievement of a mean mark of $70 \%$ or above).
} 
produce academic vulnerability; these characteristics include level of 'preparedness', gender, age, socio-economic background, parental educational background, university type, and mode of study i.e. whether a student is registered part-time or full-time (Smith \& Naylor 2001; Christie et al. 2004; Richardson 2008; Thomas 2012; Theile, Singleton, Pope \& Stanistreet 2015). It has been further noted that variation in academic outcomes for different ethnic groups exists underneath the broad, umbrella category of 'BME' students, with Black students, in particular, being highlighted as vulnerable to academic challenges in research focused on the UK (Fielding et al. 2008; Richardson 2008).

Historically, the analytical discussion of the vulnerability of BME students to academic challenge has tended to veer between approaches giving primary emphasis to deficits within the BME student groups themselves, and those primarily emphasising sector-side explanations. 'Deficit models' explain the attainment gap with primary reference to prior qualification deficits and student academic and social engagement deficits (see, for example, interview material from HE staff cited in Jacobs et al. 2007). Sector-side explanations (see, for example: Jacobs et al. 2007; Stephenson 2012) emphasise the role of HE itself, its systems, staff and processes, in producing a context within which BME students have more negative experiences than White students, leading to their relative under-achievement.

In more recent years the emphasis within the most effective research focused on explaining both retention and attainment gaps generally, has turned decisively away from what Tinto has referred to in the US context as 'blaming the victim' (2007: 2), and towards advancing a more holistic assessment of identifiable gaps. In terms of the ethnicity attainment gap, research has most recently endeavoured to develop a more detailed understanding of what it is about the HE context that can produce 
comparatively negative academic experiences and outcomes for some groups of BME students (Jacobs et al. 2007; Stephenson 2012; Cotton et al. 2015; Runnymede 2015). Key research, in particular by Richardson (2004; 2008; 2015), however, has been critical in drawing attention to two related and important points in relation to this project. First, our relative lack of knowledge, and, secondly, the contingent nature of attainment gaps that have been identified as aligned to different student characteristics. His research points to variations that occur across the same groups of students when they are in different HE contexts, or at different times (see also Woodfield \& Earl-Novell 2006). As Richardson has suggested, such fluidity points to the 'intrinsically social' nature of attainment gaps generally (Richardson, 2004, p. 324). Most recently, and specifically regarding observed ethnic attainment gaps, he concluded:

\footnotetext{
They are only partly explained by ethnic differences in entry qualifications. They vary from one institution to another and from one subject area to another. This suggests that they result in part from teaching and assessment practices in different institutions and subjects. We do not really know whether ethnic differences in attainment are reflected in variations in the student
} experience. (2015: 278)

There is a similarly striking lack of research focusing on students who are excluded from HE for non-academic reasons, and none that focuses specifically on the relationship between ethnicity and non-academic exclusion. In relation to evidence from the secondary and tertiary educational sectors, where the greater likelihood of exclusion for some BME groups has been clearly demonstrated (Runnymede 2002; EHRC 2010, 2015), explanations have also tended to emphasise 'in-school factors', such as low teacher expectations and poor teacher-pupil interactions, the cultural privileging of majority student knowledge and 'institutional racism', and 'out-of-school factors', such as BME students' lack of prior attainment and 'anti-academic' attitudes (Stamou, Edward, 
Daniels and Ferguson 2014: 7; see also Runnymede 2002: 3). The 'in-school' phenomena identified here find echoes in research specifically claiming that BME students experience marginalisation from key areas and opportunities within HE, producing a number of outcomes, ranging from less access to university places, especially to places in higher ranked institutions, through to exclusion from the majority-centric customs, cultures and practices within HE learning environments, and lower levels of quality engagement between BME students and HE staff (Shiner \& Modood 2002; Christie et al. 2004; ECU/HEA 2008; Reay, Crozier \& Clayton 2009; Singh 2011; ECU 2012; Arc Network 2013; Boliver 2014; Mirza 2015; Crozier, Burke \& Archer 2016). Recent, qualitative, research has highlighted the passive and active 'othering' of BME students that can take place within the Academy, partly through the maintenance of 'White norms' (Crozier et al., 2016); this work suggests that BME students have less access to the mainstream experience of $\mathrm{HE}$ and to its core cultures and practices. BME students themselves have also been active in articulating experiences of this process of 'othering' (see, for instance, the 'I, too, am Oxford' initiative, 2014)

In both the literature relevant to academic failure, and that relevant to exclusion, the role played by the disciplinary context within which a student studies for an undergraduate degree remains a neglected area and one requiring further attention and research (Woodfield \& Earl-Novell 2006; Smith \& White 2015). Variability in the outcomes of students from different socio-demographic groups across disciplines, suggests the way we organize broad knowledge fields within HE, contributes to differentiated outcome patterns. This article seeks also to address the impact of disciplinary context as a mediating factor in the relationship between ethnicity and the requirement to withdraw. In addressing the latter issue, it seeks to further explore the contingent and fluid nature of student outcome patterns. 


\section{Methodology}

\section{Data: participants, definitions, analytical approach}

The data that the analysis underpinning this article is based upon comprises a bespoke set supplied by the Higher Education Statistical Agency (HESA) ${ }^{4}$. It includes all undergraduate students enrolled to take a degree in an English HEI in the academic year 2010-11, and in a single, identifiable discipline.

\section{Ethnicity}

Students domiciled in the UK are required to report their ethnic origin before they register to study in an English HEI. Students domiciled outside the UK are not required to report their ethnic origin when they attend an English HEI, and so were removed from the dataset prior to analysis. UK-domiciled students reporting their ethnic origin select from the following categories: Black or Black British - Caribbean; Black or Black British - African; Other Black background; Asian or Asian British - Indian; Asian or Asian British - Pakistani; Asian or Asian British - Bangladeshi; Chinese; Other Asian background; Other Mixed background; White. Students refusing to supply this information or reporting their ethnicity as 'Unknown' were excluded for the purposes of analysis.

\section{Continuation/non-continuation status}

In terms of the broad 'continuation' marker that HESA deploys, students are either identified as a continuing with their studies or not continuing. Those in the latter category include students who have successfully completed their degree and these students, along with continuing students, were removed from the dataset after a

\footnotetext{
${ }^{4}$ Bespoke data-set: 34843. Please note that HESA cannot accept responsibility for any inferences or conclusions derived from the data by third parties.
} 
preliminary analysis of student withdrawal by ethnicity was undertaken (see Table 1 below). The remaining dataset therefore comprises all students who left their courses without collecting their award i.e. all leavers, and the subsequent analysis was undertaken only on leavers. The full list of categories that leavers are assigned to is as follows: 'Successful completion of a course (result unknown)'; 'Transferred to another institution'; 'Health reasons'; 'Death'; 'Financial reasons'; 'Other personal \& dropped out'; 'Written off after lapse of time'; 'Gone into employment'; 'Other'; 'Unknown'; 'Academic Failure/not permitted to progress'; 'Exclusion'. Students recorded under 'transferred to another institution' and 'Successful completion of a course (result unknown)' were removed for the purposes of analysis, as there remains uncertainty within these categories about their future progress on degree-conferring courses. Students recorded under 'Death' and 'Unknown' and also were removed from the dataset. Students leaving for all reasons except 'Academic Failure/not permitted to progress' (abbreviated here to 'Academic Failure') and 'Exclusion' are deemed to have withdrawn voluntarily, while students falling into these latter two categories are deemed to have been 'required to withdraw'. Students leaving due to 'Academic Failure' are defined by HESA as failing assessment at any stage. Students leaving under the 'Exclusion' category do so because they have been deemed to have broken institutional rules, either behavioural or financial (HESA 2011).

\section{Socio-demographic and on-course characteristics}

As well as information relating to a student's ethnicity, the dataset included a number of items relating to students' other socio-demographic background characteristics that were pertinent to this analysis ${ }^{5}$, and a number of items related to on-course characteristics; in

\footnotetext{
5 Another possible predictor variable - students' Tariff point total from pre-university qualifications could not be included in the model as it was missing from approximately $80 \%$ of cases.
} 
both cases these had been identified as likely predictors of withdrawal from initial analyses and from previous research highlighting vulnerability characteristics associated with withdrawal. In terms of socio-demographic background characteristics, the following were included in the analysis: gender; socio-economic class; whether a parent had an HE qualification or not; age ${ }^{6}$. In terms of on-course characteristics, the following variables were included in the analysis: mode of study; HEI type attended; Distance between pre-HE home address and HE home address.

\section{$\underline{\text { Gender }}$}

Students identified themselves as 'female', 'male', or of an indeterminate gender. Three students who identified as of indeterminate gender were removed for the purposes of analysis and for confidentiality reasons.

\section{$\underline{\text { Socio-economic class }}$}

Students provided information on socio-economic class using an occupation-based system $^{7}$. For applicants prior to 2008-09, this classification was based on the socioeconomic background/occupation of students aged 21 and over at the start of their course, or for students under 21 the socio-economic background of their parent, stepparent or guardian who earned the most. For applicants for 2008-09 entry only, this classification was based on the socio-economic background/occupation of the student if they were not in full-time education, or for students in full-time education, the socioeconomic background of their parent, step-parent or guardian.

\footnotetext{
${ }^{7} \mathbf{1}=$ Higher managerial and professional occupations; 2 = Lower managerial and professional occupations; $\mathbf{3}$ = Intermediate occupations; $\mathbf{4}=$ Small employers and own account workers; $\mathbf{5}=$ Lower supervisory and technical occupations; $\mathbf{6}=$ Semi-routine occupations; $\mathbf{7}=$ Routine occupations; $\mathbf{8}=$ Never worked and long-term unemployed; $9=$ Not classified.
} 


\section{$\underline{\text { Parental education }}$}

This measure recorded whether a student's parents had attained a higher education qualification or not.

\section{Age}

Students were identified as of 'traditional' age, defined as under 21 at the start of their degree, or as of 'mature' age, defined as over 21 at the start of the their degree.

\section{Mode of study}

Students were defined as full-time or part-time. Full-time students were those normally required to attend an institution for periods amounting to at least 24 weeks within the year of study. Part-time students were those recorded as studying part-time, or studying full-time on courses lasting less than 24 weeks, on block release, or studying during the evenings only.

\section{Higher Education Institution type}

The higher education institutions that students were registered for their degrees with were categorised as either 'Russell Group' or 'Other'. 'Russell Group' HEIs are a selfselected group of 24 comparatively large public universities, 20 of which are institutions located within England, and which are associated with a concentration of post-graduate research activity, research funding, and research defined as 'world-leading' in the UK's Research Excellence Framework'. Although the distinctive quality and status claims of this group of universities is contested (see, for example: Boliver 2015), such institutions are usually highly-ranked within national and international league tables. 


\section{$\underline{\text { Distance between pre-HE home address and HE home address }}$}

HESA collects data, where available ${ }^{8}$, on the distance between a student's pre-HE home address and the HE home address. A binary variable was subsequently created to distinguish between students who were studying at a nearby HEI and those who were studying at an HEI further afield. BME students, mature students, and students from lower socio-economic classes are more likely to study at a university that is within 30 miles of their pre-HE home address. Students attending an HEI within 30 miles of their pre-HE home address are also more likely to withdraw from their studies without attaining their degree and are less likely to obtain a 'good degree' (Woodfield 2014).

\section{Discipline}

Disciplinary boundaries were constructed to reflect subject groupings as defined by the UK's Higher Education Academy (HEA) (see Woodfield 2014).

\section{Analytical strategy}

Initial analyses comprised the production of frequencies. First, the whole final data-set ( $\mathrm{n}=1375054)$ was examined to explore the relationship between students' ethnic grouping and the incidence of them leaving their course without their degree (see Table 1 below), and to provide contextual information about selected disciplines (See Table 3). Frequencies were also produced from the 'leavers only' data-set $\left(\mathrm{n}=77289^{9}\right)$ to examine the relationship between students' ethnicity and their reasons for leaving their degree, and in relation to the provision of contextual information for subsequent disciplinary analyses (see Tables 2 and 4).

\footnotetext{
${ }^{8}$ It should be noted that data relating to distance from HEI was missing in approximately $30 \%$ of cases. ${ }^{9}$ Varying numbers in subsequent tables reflect the exclusions made from this 'Leavers only' dataset, as outlined above.
} 


\section{$\underline{\text { Required to withdraw rates within paired disciplines }}$}

To further explore the relative validity of 'deficit model' and 'sector-side' explanatory approaches (including the mediating effect of disciplinary studied), for particular groups' lower attainment and retention rates within HE, a further stage of analysis was undertaken. It is generally the case that different disciplines require students to withdraw at different rates, with some disciplines in the UK, for instance Veterinary Science, reporting no Exclusions and others, for instance History, reporting that $10 \%$ of their leavers are excluded (Woodfield 2014). The further stage of analysis was undertaken in relation to the leavers within two, paired Social Science disciplines (Business and Management and Education), and two, paired Science disciplines (Biological Science and Psychology). By exploring the role played by ethnicity in these two sets of paired disciplines, this further stage of analysis supported exploration of the extent to which the impact of ethnic background varies across the sector, and even across cognate disciplines. A series of four, binary logistic regressions were performed, each individuallynested within one of the selected disciplines. This enabled the assessment of the impact of a number of background and on-course factors on the likelihood that leavers were required to withdraw, and allowed the assessment of the impact of each variable independently, while others were held constant.

The models contained seven predictor variables ${ }^{10}:$ gender (Female/Male); age (Traditional age/Mature); Socio-economic class (1\&2/3-9); Parent with HE qualification (Yes/No); Mode of study (Full-time/Part-time); Institutional type (Russell Group/Other); Distance between pre-HE address and HEI address (Over 30 miles/Under 30 miles); and Ethnicity (White/Black/Asian/Other Mixed). In each case

10 A check for inter-correlations among predictor variables was undertaken using collinearity diagnostics in SPSS. All tolerance levels lay between .737 and .996 , indicating low multicollinearity. 
the reference category and first category was that category previously identified as being associated with a reduced risk of withdrawal from studies. The dependent variable was 'required to withdraw' / 'withdrew voluntarily'. The full range of ethnicity categories was collapsed into 4 broader categories at this stage of the analyses to ensure that a sufficient number of students were associated with each ethnic group. It should be acknowledged that this process nevertheless aggregates ethnic subgroups whose overall pattern in terms of voluntary/non-voluntary withdrawal is more nuanced (see Table 2).

All analyses were undertaken using SPSS (version 21). 


\section{Results}

$\underline{\text { Reason for leaving, overall and by ethnicity }}$

Approximate position of Table 1 here

As is evidenced in Table 1, with the exception of Chinese, and Asian or Asian British Indian students, those identifying as from a BME background were more likely to leave their courses without attaining their degree. Black or Black British students were the 
most likely to withdraw without their degree, with nine per cent or more of students in all three Black subcategories leaving under these circumstances.

Table 2 summarises the 'reason for leaving' categories that student leavers were reported under, both generally and for each ethnic group. In terms of the general picture, students leaving because of 'Academic Failure' comprise the largest category of leavers (30\%), followed by those leaving for reasons categorised as 'Other personal' (24\%), those leaving because they had completed a course (not a degree course) (16\%), and 'Other' (14\%). Much smaller percentages of students who left were registered under 'Health', 'Financial', and 'Employment' reasons - these categories collectively accounted for just $7 \%$ of all leavers - while $5 \%$ of students were 'Written Off after a time lapse' and 5\% were excluded. Overall, students who were required to withdraw from their studies, following Academic Failure or Exclusion, comprised 35\% of leavers, with the majority of those exiting because of Academic Failure. 


\section{Approximate position of Table 2 here}

Student leavers from different ethnic backgrounds were not evenly represented within those required to withdraw, with leavers from a White background being considerably less likely than other groups to exit non-voluntarily. Of White leavers $29 \%$ were required to withdraw, $24 \%$ on academic grounds while $5 \%$ were excluded. It is notable that student leavers from a White background, when compared to the sector average, were marginally over-represented within the reason categories of 'Other personal' and 'Other', and 'Left for employment'. Leavers from both a Chinese (41\%) and Other Mixed background (41\%) comprised the next least likely groups to be required to withdraw; in both cases, higher percentages of students were required to withdraw, as compared to students from a 'White' background, primarily because of elevated levels of Academic Failure. 
The student leavers most likely to be required to withdraw were students from a Black or Black British - African background (56\%); these students were over twice as likely to be excluded when compared to the sector. This group was followed by student leavers from an Other Asian background, where 54\% were required to withdraw, $49 \%$ because of Academic Failure reasons, and Other Black British students, where $52 \%$ were required to withdraw; it was notable that such students were nearly three times more likely than the sector average to exit because of 'Exclusion'. Indeed, all student leavers identifying as from a 'Black' ethnic background had elevated levels of leavers under both 'Exclusion' and 'Academic Failure' categories. This pattern contrasted with other BME groups whose over-representation within the required to withdraw categories was largely or solely accounted for by elevated levels of Academic Failure exits. It is noteworthy that the elevated levels of leavers that were required to withdraw amongst BME students, sat alongside relatively depressed levels of BME students leaving for 'Other Personal' and 'Other' reasons.

\section{Contextualising the discipline-based analyses}

As can be seen form Table 3, on the Social Science side, Business and Management has a larger percentage of students from BME backgrounds (29\%) than the sector average (21\%), while Education has a lower percentage (14\%). On the Science side, Biological Science has a slightly larger percentage of BME students $(22 \%)$ than the sector average, and Psychology has a slightly smaller one (19\%). 
Approximate position of Table 3 here

Table 4 presents the reasons why students leave the subject without their degree across the four selected disciplines. Of specific interest here is the balance between students who are required to withdraw and those that withdraw voluntarily. On the Social Science 
side, $41 \%$ of leavers within Business and Management are required to withdraw, which is higher than the sector average of 35\%; leavers were over-represented in both categories of 'Failed academically' and 'Exclusion' in this discipline. By contrast, 25\% of leavers within Education were required to withdraw, which was lower than the sector average; here the smaller percentage of those required to withdraw may be linked to the larger than average percentages of students withdrawing for 'Other personal' reasons. In terms of the Science disciplines, 35\% of student leavers within Biological Science are required to withdraw, which matches the sector average, while $32 \%$ of student leavers within Psychology fell into this category. Of particular interest here is Psychology's elevated percentages - $11 \%$ against the sector average of $5 \%$ - of students excluded.

\section{Approximate position of Table 4 here}




\section{$\underline{\text { Binary Logistic regression results }}$}

The model for Business and Management was statistically significant $\left(X^{2}(10)=114.86, p\right.$ $<.001)$. As can be seen in Table 5, three independent variables made a unique, statistically significant contribution to the model predicting the likelihood of student leavers being required to withdraw from studies. Men had higher odds of being required to withdraw $(\mathrm{OR}=1.68 ; 95 \% \mathrm{CI}=1.28-2.22)$, and mature aged students $(\mathrm{OR}=.68 ; 95 \%$ $\mathrm{CI}=.47-.98)$ were less likely to be required to withdraw than traditional aged students. The strongest predictor of being required to withdraw was, however, ethnicity. Black students were over 4 times more likely to be required to withdraw $(\mathrm{OR}=4.52 ; 95 \%$ $\mathrm{CI}=3.03-6.74)$ than White students, while Asian students were over 3 times more likely $(\mathrm{OR}=3.24 ; 95 \% \mathrm{CI}=2.28-4.59)$ and students identifying as Other Mixed we twice as likely $(\mathrm{OR}=2.03 ; 95 \% \mathrm{CI}=1.16-3.53)$.

By comparison, within Education, the model did not achieve statistical significance $\left(X^{2}\right.$ $(10)=17.93, p=.06)$. Of particular note is the fact that student leavers from BME backgrounds were not significantly more likely to be required to withdraw from their studies.

The model for Biological Science was statistically significant $\left(X^{2}(10)=88.96, p<.001\right)$. As can be seen from Table 6, three independent variables made a unique statistically significant contribution to the model predicting the likelihood of leavers being required to withdraw. As with Business and Management, leavers from all three broad BME backgrounds were more likely to be required to withdraw from their studies than White student leavers. Black students were nearly four times more likely $(\mathrm{OR}=3.88 ; 95 \%$ $\mathrm{CI}=2.06-7.30)$, while Asian student leavers were over five times more likely (OR = 5.11; $95 \% \mathrm{CI}=3.05-8.57)$ and leavers from an Other Mixed background were over twice as 
likely to be required to withdraw (OR $-2.76 ; 95 \% \mathrm{CI}=1.10-7.00)$. Additionally, leavers from non-Russell Group HEIs were over three times more likely to be required to withdraw from their studies $(\mathrm{OR}=3.34 ; 95 \% \mathrm{CI}=1.46-7.63)$, and leavers whose preuniversity address was less than 30 miles away from the HEI they were studying at, were also more likely to be required to withdraw (OR $=1.73$; 95\% $\mathrm{CI}=1.14-2.64)$.

The model for the second Science discipline, Psychology, was also statistically significant $\left(X^{2}(10)=42.73, p<.001\right)$. Of most interest here is the fact that, although three independent variables made a unique statistically significant contribution to predicting the likelihood of student leavers being required to withdraw - gender, mode of study and distance between pre-university address and HEI - ethnicity did not. 
Approximate position of Tables $5 \& 6$ here 



\section{Discussion and conclusion}

Students from most BME backgrounds were more likely to withdraw from their studies than White students. Amongst leavers, all groups of BME students were more likely to be required to withdraw than White students. In the cases of Black or Black British African, Other Black British, and Other Asian leavers, the majority of the students were required to withdraw rather than withdrawing voluntarily. Furthermore, Black students here were found to be those particularly over-represented in the Exclusion category of those required to withdraw suggesting a continuation of the trend wherein such students have elevated levels of exclusion at primary and secondary educational levels (Runnymede Trust 2002; EHRC 2010, 2015; DofE 2012).

Of interest is the fact that the elevated levels of BME leavers required to withdraw sat alongside comparatively depressed levels of students withdrawing for 'Other Personal' and 'Other' reasons, and this finding may well reflect less positive engagement between some groups of BME students and HEI staff (ECU/HEA 2008; ECU 2012). If students are engaging with academic and professional services staff often and fruitfully, then it seems reasonable to assume that they are more likely to enter into a dialogue in relation to any problems they may be experiencing, which, in turn, may impact positively on withdrawal rates overall, or, at the very least, on the rates at which leavers' withdrawals are categorised as voluntary.

The results from the discipline-specific, Logistic Regression analyses were of particular interest, specifically for two reasons. First, it was confirmed that, in one Social Science discipline (Business and Management), and one Science discipline (Biological Science), being a leaver from a Black, Asian or Other Mixed background was a significant predictor of being required to withdraw. This was when other factors that may be 
associated with increased vulnerability to withdrawal, were controlled for, confirming that ethnicity is playing an independent role in student outcomes within HE (Richardson 2008, 2015). Following on from other research focusing on UK students (e.g.

ECU/HEA 2008; Fielding et al. 2008; Richardson 2008), Black and Asian students seem to be particularly vulnerable to negative outcomes within HE.

Secondly, the discipline-specific analyses confirmed that this pattern was not universal across the sector, for in cognate Social Science (Education) and Science (Psychology) disciplines, ethnicity was not a predictor of whether leavers were required to withdraw or not. The contextual information relating to the selected disciplines makes clear this variation is not related to the density of BME students within a particular discipline; for instance, in Business and Management, there is a larger percentage of BME students than in Education, and yet it is in the former that we see ethnicity emerge as a predictor of being required to withdraw. It is the case, that within Business and Management, a higher percentage of students are required to withdraw overall; however, this cannot explain the independent role of ethnicity as a predictor of being required to withdraw. In Biological Science, where the required to withdraw rate is the same as the sector average, ethnicity remains a significant predictor.

These findings, therefore, suggests that the composition of the required to withdraw category is, to some extent, a determination of disciplinary cultures, customs and practices rather than characteristics of the students themselves, although they offer no further insight into the precise nature and role of such cultures. They support Richardson's work in echoing his conclusion that we lack collective knowledge about why ethnicity has an independent impact on outcome (2015), but also that, even in the context of this knowledge deficit, the fluidity of outcome patterns for different groups, 
points to the 'intrinsically social' nature of factors producing outcomes (Richardson, 2004, 2008; Woodfield \& Earl-Novell 2006). These findings also, therefore, concur with Jacobs et al. (2007) and Stephenson (2012) that there is little analytical mileage in focusing on individualistic or 'deficit' approaches', which emphasise students' characteristics when attempting to better understand differentiated student outcomes. Rather we should focus on exploring how such characteristics may co-produce different treatments and outcomes within institutions (see, for example: Crozier, Burke \& Archer 2016). More specifically, the findings suggest that consideration of sector-side phenomena, such as the discipline in which a student studies, should play a more central role in future research.

There are a number of potential implications of these findings for HEIs, and specifically, for HEI managers. They emphasise the socio-political nature of university processes and the composition of abstract categories such as 'reason for leaving' categories. The variation in practices, in terms of requiring students to withdraw across the different disciplines, that is identified here, emphasises that outcomes are a product of densely and complexly embedded social practices. The findings therefore raise important questions about the nature of the 'student experience' offered to students, and whether this is as inclusive, and as consistent, as it might be. The findings further support previous calls for improved data collection practices in relation to ethnicity within the UK (Van Dyke \& Gunaratnam 2000; Jacobs, Owen, Sergeant \& Schostak 2007; ECU/HEA 2008; Richardson 2008) and elsewhere (Meeuwisse et al. 20101 European Commission/EACEA/Eurydice 2014); this is an especially relevant message for those countries where such data are not collected. In those geographical regions where ethnicity data exists, these findings support the case for its better utilization, following 
Richardson's suggestion that much of what passes for 'ethnic monitoring' in UK HE is often no more than 'ethnic enumeration' (2008: 46). Without addressing data-deficit issues, it will be difficult to improve our collective awareness of the patterns embedded within student progress trends and therefore will prove harder to better underpin improvements in organisational decision-making regarding the processes that lead to students' withdrawal, especially their non-voluntary withdrawal.

It is hoped that this article has also made a case for treating non-voluntary withdrawal as a distinct category from voluntary withdrawal, and in doing so, offers an alternative focus to that of previous research which has almost exclusively focused on voluntary withdrawal (Berger \& Braxton 1998; Wilcox et al 2005; Bozik 2007; Tinto 2007; Severiens \& Wolff 2008; Roberts 2012; Thomas 2012). In terms of future research, it is clear that there would be value in increasing institutional efforts to access affected groups' qualitative accounts of the processes that led to their outcomes (ECU/HEA 2008: 4). 
Bibliography

Arc Network (Aimhigher Research \& Consultancy Network) (2013) Literature review of research into widening participation to bigher education: Report to HEFCE and OFF $A$ by ARC

Network. Available online at:

http://www.hefce.ac.uk/media/hefce/content/pubs/indirreports/2013/Literature, revie w,of,WP,to,HE/Literature $\% 20$ review $\% 20$ of $\% 20$ research $\% 20$ into $\% 20 \mathrm{WP} \% 20$ to $\% 20 \mathrm{HE}$ .pdf (accessed 1 October 2015).

Berger, J.B. \& Braxton, J.M. (1998) Revising Tinto's interactionalist theory of student departure through theory elaboration: examining the role of organisational attributes in the persistence process, Research in Higher Education, 39(2), 103-119.

Boliver, V. (2013) How fair is access to more prestigious UK universities?, The British Journal of Sociology, 64(2), 344-364.

Boliver, V. (2015) Are there distinctive clusters of higher and lower status universities in the UK?. Oxford Review of Education 41(5), 608-627.

Bozik, R. (2007) Making it through the first year of college: The role of students' economic resources, employment and living arrangements, Sociology of Education, 80(3), 261-284.

Broecke, S. and Nicholls, T. (2007) Ethnicity and degree attainment, DfeS Research Report RW92. London: DfES. Available online at: 
http://webarchive.nationalarchives.gov.uk/20130401151715/http://www.education.gov .uk/publications/eOrderingDownload/RW92.pdf (accessed 1 October 2015).

Carter, D. F (2006) Key issues in the persistence of underrepresented minority students, New Directions for Institutional Research, 2006(130), 33-46.

Christie, H., Munro, M. \& Fisher, T. (2004) Leaving university early: exploring the differences between continuing and non-continuing students, Studies in Higher Education, 29(5), 617-636.

Cotton, D.R.E, Joyner, M., George, R. \& Cotton, P.A. (2015) Understanding the gender and ethnicity attainment gap in UK higher education, Innovations in Education and Teaching International.

Crozier, G. Burke, P-J. \& Archer L. (2016) Peer relations in higher education: raced, classed and gendered constructions and Othering, Whiteness and Education, 1(1), 39-53.

DofE (Department of Education) (2012) A profile of pupil exclusions in England, Education Standards Analysis and Research Division, Research Report DFE-RR190. Available online:

https://www.gov.uk/government/uploads/system/uploads/attachment data/file/1834 98/DFE-RR190.pdf (accessed 1 October 2015).

ECU and HEA (2008) Ethnicity, gender and degree attainment project: final report. Available online at: www.ecu.ac.uk/publications/ethnicity-gender- and-degree-attainment-report (accessed 1 October 2015). 
ECU (2012) Male students: engagement with academic and pastoral support services. Available at: http://www.ecu.ac.uk/publications/male-students-engagement-with-academic-andpastoral-support-services/ (accessed 1 October 2015).

EHRC (Equality and Human Rights Commission)(2010) How fair is Britain? Triennial Review 2010. Available online at: http://www.equalityhumanrights.com/sites/default/files/documents/triennial review/ how fair is britain - complete report.pdf (accessed 1 October 2015).

EHRC (Equality and Human Rights Commission) (2015) Is Britain fairer? The state of equality and buman rights 2015. Available online at: http://www.equalityhumanrights.com/sites/default/files/uploads/IBF/Finalreports/EHRC IBF MainReport acc.pdf (accessed 1 October 2015).

Eimers, M.T., and G.R. Pike. (1997) Minority and nonminority adjustment to college: Differences or similarities, Research in Higher Education, 38(1). 77-97.

Engle, J. and Tinto, V. (2008) Moving beyond access: college success for low-income, first-generation students. Washington, D. C.: Pell Institute for the Study of Opportunity in Higher Education. Available online at: http:// files.eric.ed.gov/fulltext/ED504448.pdf (accessed 1 October 2015).

European Commission/EACEA/Eurydice (2014). Modernisation of higher education in Europe: access, retention and employability 2014. Eurydice Report. Luxembourg: Publications Office of the European Union. Available online at: 
http://eacea.ec.europa.eu/education/eurydice/documents/thematic reports/165EN.pd $\underline{f}$ (accessed 1 October 2015).

Fielding, A., Charlton, C. Leckie, G., Kounali, D. (2008) Degree attainment, ethnicity and gender: Interactions and the modification of effects Equality Challenge Unit/Higher Education Academy: a Report. Available online at: http://www.bristol.ac.uk/medialibrary $/$ sites $/ \mathrm{cmm} /$ migrated/documents/degree-eth-gender.pdf (accessed 1 October 2015).

HEA/Foster, E., Raven, N. \& Thomas, L. \& Woodfield, R. (2011) Male access and success in higher education: Higher Education Academy Discussion paper. A Higher Education Academy Report. Available online at: https://www.heacademy.ac.uk/sites/default/files/maleaccess.pdf (accessed: 1 October 2015).

Higher Education Statistical Agency (HESA) (2011) Student record 2011/12: reason for ending instance. Available online at: https://www.hesa.ac.uk/component/studrec/show file/11051/a\%5E \%5ERSNEND. html (accessed 1 October 2015).

Hobson-Horton, L.D., \& Owens, L. (2004) From freshman to graduate: Recruiting and retaining minority students, Journal of Hispanic Higher Education, 3(1), 86-107

Hofman, A., \& van den Berg, M. (2003) Ethnic-specific achievement in Dutch higher education, Higher Education in Europe, 28(3), 371-89. 
I, too, am Oxford (2014) Available online at: http://itooamoxford.tumblr.com/ (accessed 1 July 2016)

Jacobs, S., Owen, J. Sergeant, P and Schostak, J. (2007) Ethnicity and gender in degree attainment: An extensive survey of views and activities in English HEIs An Equality Challenge Unit/Higher Education Academy report.

Meeuwisse, M., Severiens, S.E., \& Born, M. P. (2010) Reasons for withdrawal from higher vocational education. A comparison of ethnic minority and majority non-completers, Studies in Higher Education, 3(1), 93-111.

Ministry of Education, New Zealnd (2015) Profile \& Trends: Tertiary Education, Outcomes and Qualification Completions 2014, Ministry of Education, New Zealand. Available online at:

https://www.educationcounts.govt.nz/ data/assets/pdf file/0003/170148/2014Profile-and-Trends-Tertiary-Education-Outcomes-and-Qualification-Completions.pdf (accessed 5 August 2016).

Mirza, H. S. (2015) Respecting difference: widening participation in post-race time, in: C. Alexander \& J. Arday (Eds) Aiming higher: race, inequality and diversity in the academy, A Runnymede Perspectives Report: 27-29. Available online at: http://www.runnymedetrust.org/uploads/Aiming\%20Higher.pdf (accessed 1 October 2015).

Morning, A. (2008) Ethnic Classification in Global Perspective: A Cross-National Survey of the 2000 Census Round, Population Research Policy Review, 27(2), 239-272. 
Office of the Children's Commissioner (2012) "They never give up on you"

School Exclusions Inquiry, Executive Summary. Available online at:

https://www.childrenscommissioner.gov.uk/sites/default/files/publications/They $\% 20 \mathrm{n}$ ever $\% 20$ give $\% 20$ up $\% 20$ on $\% 20$ you $\% 20$ summary.pdf (accessed 1 October 2015 ).

Reay, D., Crozier, G. and Clayton, J. (2009) 'Fitting in' or 'standing out': working-class students in UK higher education', British Educational Research Journal, 32(1), 1-19.

Richardson, J. T. E. (2004) Contingent degree performance, The Psychologist: Bulletin of the British Psychological Society, 17(6), 323-324.

Richardson, J. T. E. (2008) The attainment of ethnic minority students in UK higher education, Studies in Higher Education, 33(1), 33-48.

Richardson, J. T.E. (2015) The under-attainment of ethnic minority students in UK higher education: what we know and what we don't know, Journal of Further and Higher Education, 39(2), 278-291.

Roberts, D. (2012) Modelling withdrawal and persistence for initial teacher training: revising Tinto's longitudinal model of departure, British Educational Research Journal, 38(6), 953-975.

Runnymede Trust (2002) Black and Minority Ethnic issues in teaching and learning: Briefing paper. Available online at: 
http://www.runnymedetrust.org/uploads/projects/education/BMEissuesDiscussionPa per.pdf (accessed 1 October 2015).

Runnymede/Alexander, C. and Arday, J. (Eds) (2015) Aiming Higher: Race, Inequality and Diversity in the Academy, A Runnymede Perspectives Report. Available online at: http://www.runnymedetrust.org/uploads/Aiming $\% 20$ Higher.pdf (accessed 1 October 2015).

Scott, D. \& Smart, W. (2005) What factors make a difference to getting a degree in New Zealand? Wellington: Ministry of Education. Available online at: http://thehub.superu.govt.nz/sites/default/files/42253 modelling-completion-factorsreport-sfs 0.pdf (accessed 1 October 2015).

Severiens, S.E., and R. Wolff. (2008) Study success of students from ethnic minority back-grounds: An overview of explanations for differences in study careers, in: M. Tight, K.H. Mok, J. Huisman \& C. Morphew (Eds), The Routledge international handbook of higher education (New York, Routledge).

Shiner, M \& Modood, T. (2002): Help or hindrance? Higher education and the route to ethnic equality, British Journal of Sociology of Education, 23(2), 209-232.

Singh, G. (2011) Black and Minority Ethnic (BME) students' Participation in Higher Education: Improving Retention and Success - a Synthesis of Research Evidence York: Higher Education Academy. http://www.heacademy.ac.uk/assets/documents/inclusion/ethnicity/BME_synthesis_F INAL.pdf (accessed 1 October 2015). 
Smith, J. \& Naylor, R. (2001) Determinants of degree performance in UK universities: a statistical analysis of the 1993 student cohort, Oxford Bulletin of Economics and Statistics, 63(1), 29-60.

Smith, E. \& White, P. (2015) What makes a successful undergraduate? The relationship between student characteristics, degree subject and academic success at university, British Educational Research Journal, 41(4), 686-708.

Stamou, E. Edwards, A. Daniels, H and Ferguson, L (2014) Young People At-risk of Dropour from Education: Recognising and Responding to their Needs University of Oxford Report for The Oxford Centre for Sociocultural and Activity Theory Research, Department of Education. Available online at: http://www.education.ox.ac.uk/wordpress/wpcontent/uploads/2010/07/Young-people-at-Risk-of-Drop-Out-from-Education.pdf (accessed 1 October 2015).

Stevenson, J. 2012. Black and Minority Ethnic Student Degree Retention and Attainment York: Higher Education Academy. Available online at: http://www.heacademy.ac.uk/assets/documents/retention/Summit/bme_summit_final _report.pdf (accessed 1 October 2015).

Thiele, T, Singleton, A., Pope, D. \& Stanistreet, D. (2015) 'Predicting Students' academic performance based on school and socio-demographic characteristics', Studies in Higher Education, 41(8), 1424-1446. 
Thomas, L. (2012) Building students engagement and belonging in Higher Education at a time of change: final report from the What Works? Student Retention and Success programme. Available online at:

https://www.heacademy.ac.uk/sites/default/files/what works final report.pdf (accessed 1 October 2015).

Tinto, V. (1997) Classrooms as communities: exploring the educational character of student persistence, The Journal of Higher Education, 68(6), 599-623.

Tumen, S. Shulruf, B. \& Hattie, J. (2008) Student pathways at the university: patterns and predictors of completion, Studies in higher Education, 33(3), 233-252.

Van Dyke, R. \& Gunaratnam, Y. (2000) Ethnic monitoring in higher education: Some reflections on methodology, International Journal of Social Research Methodology, 3(4), 325-345.

Wilcox, P., Winn, S. and Fyvie-Gauld, M. (2005) It was nothing to do with the university, it was just the people: the role of social support in the first year experience of higher education, Studies in Higher Education. 30(6), 707-722.

Wolff, R. \& Pasztor, A. (2008) Equal Opportunity in a Public System: Experiences of Ethnic Minority Students in Dutch Higher Education in: F. Lazin \& M. Evans (Eds) Higher Education and Equality of Opportunity: Cross-National Perspectives (Maryland: Rowman \& Littlefield).

Woodfield, R. (2014) Undergraduate Retention and Attainment across the Disciplines Higher Education Academy Report. Available online at: 
https://www.heacademy.ac.uk/sites/default/files/resources/undergraduate retention a nd attainment across the disciplines.pdf (accessed: 1 October 2015).

Woodfield, R. \& Earl-Novell, S. (2006) An assessment of the extent to which subject variation between the arts and sciences in relation to the award of a first class degree can explain the 'gender gap' in UK universities, British Journal of Sociology of Education, 27 (3), $355-372$. 

Tables - Undergraduate students who are required to withdraw from university: the role of ethnicity

Table 1 - Percentage ${ }^{1}$ of students from available ethnic categories who left their course without attaining their degree, by ethnicity, England 2010-11

\begin{tabular}{ll}
\hline & $\begin{array}{l}\% / \text { number of students in each } \\
\text { ethnic group leaving without } \\
\text { degree }\end{array}$ \\
Black or Black British - Caribbean & $10(2120)$ \\
Black or Black British - African & $9(5005)$ \\
Other Black British & $11(485)$ \\
Asian or Asian British - Indian & $5(2255)$ \\
Asian or Asian British - Pakistani & $7(2153)$ \\
Asian or Asian British - Bangladeshi & $7(813)$ \\
Chinese & $5(469)$ \\
Other Asian & $7(1420)$ \\
Other Mixed & $7(3369)$ \\
White & $5(48304)$ \\
\hline
\end{tabular}

\footnotetext{
${ }^{1}$ Percentages are rounded up if they are above the 0.5 mark and down if below. Due to this rounding strategy, aggregated percentages may not equal $100 \%$. All other numbers reported and rounded to 2 decimal places.
} 
Table 2: Student leavers only: reason for withdrawing from their course without their degree, by ethnicity, England, 2010-11

\begin{tabular}{|c|c|c|c|c|c|c|c|c|c|c|}
\hline & 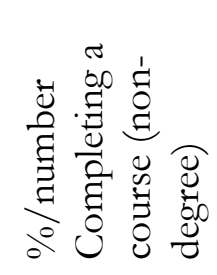 & 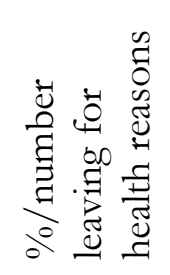 & 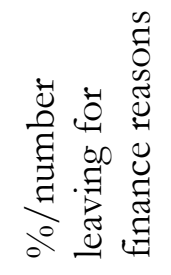 & 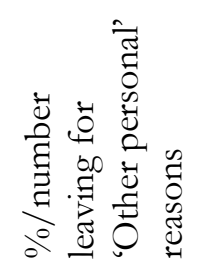 & 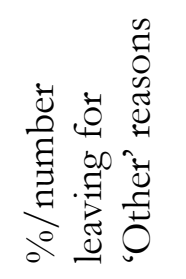 & 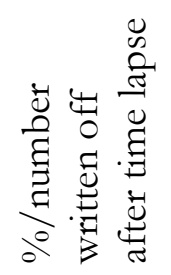 & 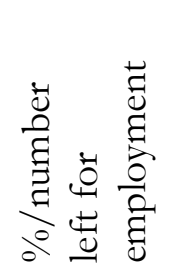 & 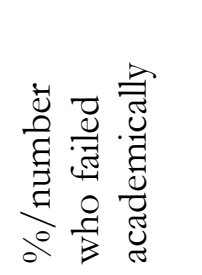 & 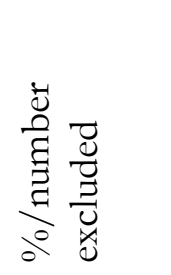 & 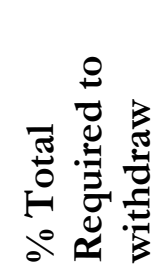 \\
\hline All leavers & $16(9205)$ & $3(1400)$ & $2(1187)$ & 24 (13367) & $14(7800)$ & $5(2723)$ & $2(1078)$ & 30 (16836) & $5(2970)$ & 35 \\
\hline $\begin{array}{l}\text { Black or } \\
\text { Black British - } \\
\text { Caribbean }\end{array}$ & $17(250)$ & $2(29)$ & $2(36)$ & $14(210)$ & $9(125)$ & $8(112)$ & $1(9)$ & $40(586)$ & $8(121)$ & 47 \\
\hline $\begin{array}{l}\text { Black or } \\
\text { Black British - } \\
\text { African }\end{array}$ & $15(512)$ & $1(25)$ & $2(79)$ & $11(374)$ & $8(255)$ & $7(218)$ & $0(12)$ & $45(1484)$ & $11(359)$ & 56 \\
\hline $\begin{array}{l}\text { Other Black } \\
\text { British }\end{array}$ & $16(52)$ & $1(4)$ & $4(12)$ & $12(40)$ & $9(31)$ & $6(20)$ & $0(1)$ & $38(126)$ & $14(46)$ & 52 \\
\hline $\begin{array}{l}\text { Asian or } \\
\text { Asian British - } \\
\text { Indian }\end{array}$ & $19(319)$ & $2(26)$ & $1(21)$ & $17(285)$ & $11(178)$ & $5(76)$ & $2(24)$ & $41(670)$ & $3(50)$ & 44 \\
\hline $\begin{array}{l}\text { Asian or } \\
\text { Asian British - } \\
\text { Pakistani }\end{array}$ & $18(300)$ & $1(17)$ & $2(30)$ & $18(293)$ & $11(174)$ & $4(69)$ & $1(15)$ & $40(656)$ & $5(83)$ & 45 \\
\hline $\begin{array}{l}\text { Asian or } \\
\text { Asian British - } \\
\text { Bangladeshi }\end{array}$ & $15(90)$ & $1(5)$ & $2(13)$ & $22(131)$ & $9(54)$ & $3(16)$ & $1(4)$ & 44 (264) & $4(21)$ & 48 \\
\hline Chinese & $19(65)$ & $2(5)$ & $1(3)$ & $18(61)$ & $13(46)$ & $5(16)$ & $2(7)$ & 38 (131) & $3(10)$ & 41 \\
\hline Other Asian & $13(131)$ & $1(14)$ & $2(17)$ & $14(140)$ & $10(100)$ & $6(65)$ & $1(9)$ & $49(511)$ & $5(50)$ & 54 \\
\hline Other Mixed & $16(377)$ & $2(39)$ & $2(47)$ & $20(486)$ & $13(326)$ & $6(150)$ & $1(24)$ & $35(853)$ & $6(137)$ & 41 \\
\hline White & $16(5860)$ & $3(1114)$ & $2(731)$ & $27(9822)$ & $15(5481)$ & $5(1666)$ & $3(923)$ & $24(8702)$ & $5(1854)$ & 29 \\
\hline
\end{tabular}


Table 3 - Composition of student body across paired disciplines, by broad reported ethnic category - England 2010/11

\begin{tabular}{|c|c|c|c|c|}
\hline & 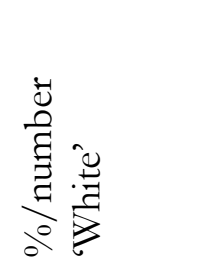 & 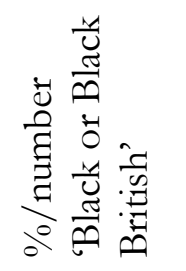 & 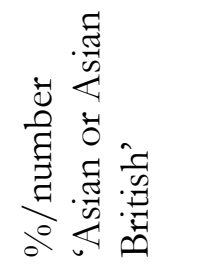 & 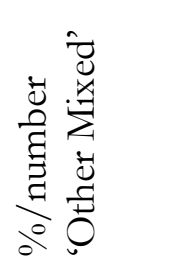 \\
\hline $\begin{array}{l}\text { Sector as a whole } \\
\text { Social Science }\end{array}$ & 79 (957865) & $7(84600)$ & $10(114300)$ & $4(48995)$ \\
\hline Business \& Management & $72(56459)$ & $10(7726)$ & $14(10777)$ & $5(3554)$ \\
\hline $\begin{array}{l}\text { Education } \\
\text { Science }\end{array}$ & $86(69239)$ & $5(3873)$ & $6(5111)$ & $3(2192)$ \\
\hline Biological Science & $77(28581)$ & $6(2294)$ & $12(4557)$ & $4(1548)$ \\
\hline Psychology & $81(38402)$ & $6(3036)$ & $8(3793)$ & $5(2265)$ \\
\hline
\end{tabular}


Table 4: Reasons for student leavers to withdraw from their studies without their degree, by paired disciplines: Business \& Management Education, Biological Science \& Psychology

\begin{tabular}{|c|c|c|c|c|c|c|c|c|c|c|}
\hline & 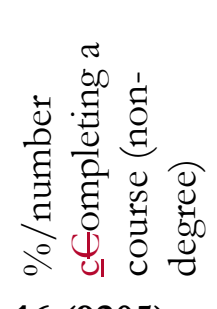 & 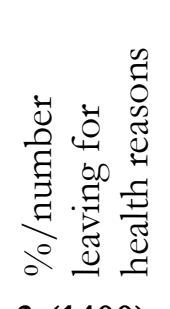 & 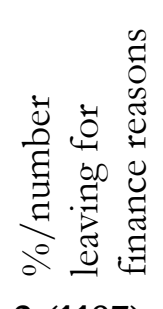 & 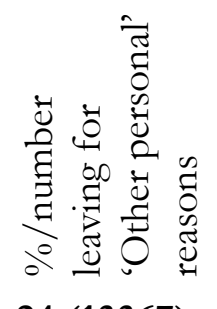 & 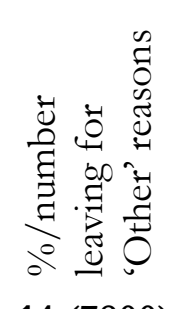 & 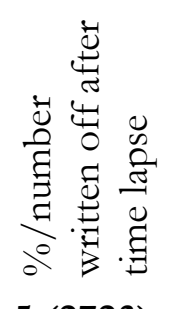 & 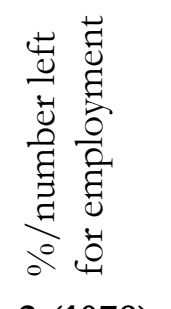 & 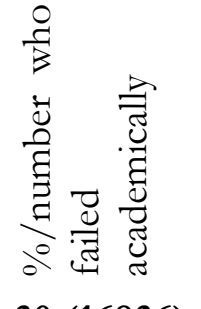 & 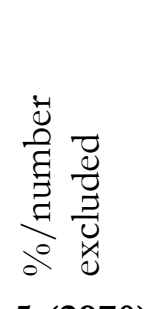 & 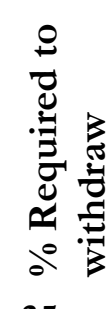 \\
\hline $\begin{array}{l}\text { Sector as a } \\
\text { whole }\end{array}$ & $16(9205)$ & $3(1400)$ & $2(1187)$ & 24 (13367) & $14(7800)$ & $5(2723)$ & $2(1078)$ & 30 (16836) & $5(2970)$ & 35 \\
\hline \multicolumn{11}{|l|}{$\begin{array}{l}\text { Social Science } \\
\text { disciplines }\end{array}$} \\
\hline $\begin{array}{l}\text { Business \& } \\
\text { Management }\end{array}$ & $14(622)$ & $2(75)$ & $2(89)$ & $20(896)$ & $15(704)$ & $6(250)$ & $2(85)$ & 34 (1533) & 7 (314) & 41 \\
\hline Education & $17(662)$ & $4(138)$ & $3(96)$ & $29(1118)$ & $14(524)$ & $6(238)$ & $3(97)$ & 21 (805) & $4(150)$ & 25 \\
\hline \multicolumn{11}{|l|}{$\begin{array}{l}\text { Science } \\
\text { disciplines }\end{array}$} \\
\hline $\begin{array}{l}\text { Biological } \\
\text { Science }\end{array}$ & $20(348)$ & $2(34)$ & $2(41)$ & $22(374)$ & $14(236)$ & $4(64)$ & $2(39)$ & 31 (531) & $4(67)$ & 35 \\
\hline Psychology & $16(364)$ & $3(56)$ & $2(33)$ & $26(429)$ & $11(178)$ & $6(104)$ & $2(39)$ & $21(348)$ & $11(178)$ & 32 \\
\hline
\end{tabular}


Table 5: Social Science disciplines - Logistic regression for predicting required to withdraw status; a comparison of Business \& Management and Education

\begin{tabular}{|c|c|c|c|c|c|c|c|c|c|}
\hline & 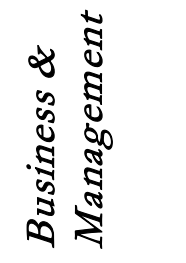 & & & & & 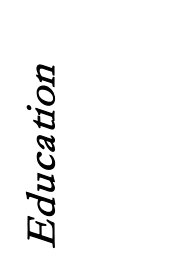 & & & \\
\hline & $\% /$ number & $\begin{array}{l}\text { Odds } \\
\text { Ratios }\end{array}$ & $\begin{array}{l}95 \% \text { CI for } \\
\text { Odds Ratios }\end{array}$ & $p$-Value & & $\% /$ number & Odds Ratios & $\begin{array}{l}95 \% \text { CI for } \\
\text { Odds Ratios }\end{array}$ & $p$-Value \\
\hline Gender & & & & & Gender & & & & \\
\hline $\begin{array}{l}\text { Women } \\
\text { (reference) }\end{array}$ & $40(446)$ & $*$ & & & $\begin{array}{l}\text { Women } \\
\text { (reference) }\end{array}$ & $79(665)$ & $*$ & & \\
\hline Men & $60(659)$ & 1.68 & $1.28-2.22$ & .00 & Men & $21(175)$ & 1.40 & $.94-2.07$ & .10 \\
\hline $\begin{array}{l}\text { Socio- } \\
\text { economic } \\
\text { Class }\end{array}$ & & & & & $\begin{array}{l}\text { Socio-economic } \\
\text { Class }\end{array}$ & & & & \\
\hline $\begin{array}{l}1 \& 2 \\
\text { (reference) }\end{array}$ & $47(520)$ & $*$ & & & $1 \& 2$ (reference) & $38(322)$ & $*$ & & \\
\hline $3-9$ & $53(585)$ & .89 & $.67-1.19$ & .44 & $3-9$ & $62(518)$ & 1.20 & $.84-1.70$ & .33 \\
\hline Parental HE & & & & & Parental HE & & & & \\
\hline $\begin{array}{l}\text { Yes } \\
\text { (reference) }\end{array}$ & 48 (527) & * & & & Yes (reference) & $40(336)$ & * & & \\
\hline No & $52(578)$ & .97 & $.73-1.27$ & .80 & No & $60(504)$ & .66 & $.47-.94$ & .02 \\
\hline Age & & & & & Age & & & & \\
\hline $\begin{array}{l}\text { Traditional } \\
\text { (reference) }\end{array}$ & $80(883)$ & $*$ & & & $\begin{array}{l}\text { Traditional } \\
\text { (reference) }\end{array}$ & $71(595)$ & * & & \\
\hline
\end{tabular}




\begin{tabular}{|c|c|c|c|c|c|c|c|c|c|}
\hline Mature & $20(222)$ & .68 & $.47-.98$ & .04 & Mature & $29(245)$ & .57 & $.36-.91$ & .02 \\
\hline $\begin{array}{l}\text { Mode of } \\
\text { Study }\end{array}$ & & & & & Mode of Study & & & & \\
\hline $\begin{array}{l}\text { Full-time } \\
\text { (reference) }\end{array}$ & $84(932)$ & * & & & $\begin{array}{l}\text { Full-time } \\
\text { (reference) }\end{array}$ & $78(658)$ & * & & \\
\hline Part-time & $16(173)$ & 1.28 & $.87-1.89$ & .21 & Part-time & $22(182)$ & 1.32 & $.83-2.11$ & .24 \\
\hline HEI type & & & & & HEI type & & & & \\
\hline $\begin{array}{l}\text { Russell } \\
\text { Group } \\
\text { (reference) }\end{array}$ & $4(42)$ & $*$ & & & $\begin{array}{l}\text { Russell Group } \\
\text { (reference) }\end{array}$ & $2(17)$ & $*$ & & \\
\hline Other & $96(1063)$ & .95 & $.47-1.90$ & .88 & Other & $98(823)$ & .81 & $.26-2.55$ & .71 \\
\hline Distance & & & & & Distance & & & & \\
\hline $\begin{array}{l}\text { Over } 30 \text { miles } \\
\text { (reference) }\end{array}$ & $52(571)$ & $*$ & & & $\begin{array}{l}\text { Over } 30 \text { miles } \\
\text { (reference) }\end{array}$ & $44(370)$ & $*$ & & \\
\hline $\begin{array}{l}\text { Under } 30 \\
\text { miles }\end{array}$ & $48(534)$ & 1.00 & $.76-1.33$ & .99 & Under 30 miles & $56(470)$ & 1.35 & $.95-1.93$ & .10 \\
\hline Ethnicity & & & & & Ethnicity & & & & \\
\hline $\begin{array}{l}\text { White } \\
\text { (reference) }\end{array}$ & $65(713)$ & $*$ & & & White (reference) & $79(662)$ & $*$ & & \\
\hline Black & $13(141)$ & 4.52 & $3.03-6.74$ & .00 & Black & $9(73)$ & 1.41 & $.79-2.52$ & .24 \\
\hline Asian & 17 (191) & 3.24 & $2.28-4.59$ & .00 & Asian & $8(69)$ & .85 & $.44-1.63$ & .62 \\
\hline Other Mixed & $5(60)$ & 2.03 & $1.16-3.53$ & .01 & Other Mixed & $4(36)$ & 1.21 & $.54-2.69$ & .64 \\
\hline
\end{tabular}

* Reference category

Note: Business \& Management: $R^{2}=.81$ (Hosmer \& Lemeshow), 10 (Cox \& Snell), .14 (Nagelkerke). Model $X^{2}(10)=114.86, p<.001$

Note re. Education: $R^{2}=.09$ (Hosmer \& Lemeshow), .02 (Cox \& Snell), .03 (Nagelkerke). Model $X^{2}(10)=17.93, p=.06$ 
Table 6: Science disciplines - Logistic regression for predicting required to withdraw status; a comparison of Biological Science and Psychology

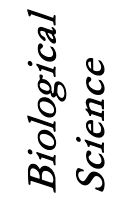

$\% /$ number Odds $\quad 95 \%$ CI for $\quad p$-Value

Gender

Women

(reference)

Men

\section{Socio-}

economic

Class

$1 \& 2$

(reference)

3-9

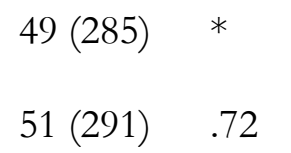

$.46-1.11$

.14

\section{Parental HE}

Yes

(reference)

No

$52(299)$

$48(277) \quad .75$

$.49-1.17$

Age

Traditional $85(488)$

(reference)

Mature
Odds Ratios

$.91-2.04$

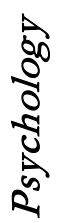

$\% /$ number Odds Ratios $\quad 95 \%$ CI for $\quad p$-Value Odds Ratios

1.15-2.61

.01

\section{Gender}

Women

(reference)

Men

$75(482)$

25 (164) 1.73

Socio-

economic

Class

$1 \& 2$

(reference)

3-9

$45(288)$

$55(358) \quad .88$

$.59-1.30$

.51

\section{Parental HE}

Yes

44 (285)

(reference)

No

$56(361) \quad 1.05$

$.70-1.57$

.83

Age

Traditional 81 (526)

(reference)

Mature

$19(120) \quad 1.40$

$.88-2.24$

.16 


\begin{tabular}{|c|c|c|c|c|c|c|c|c|c|}
\hline $\begin{array}{l}\text { Mode of } \\
\text { Study }\end{array}$ & & & & & $\begin{array}{l}\text { Mode of } \\
\text { Study }\end{array}$ & & & & \\
\hline $\begin{array}{l}\text { Full-time } \\
\text { (reference) }\end{array}$ & $91(526)$ & $*$ & & & $\begin{array}{l}\text { Full-time } \\
\text { (reference) }\end{array}$ & $92(594)$ & $*$ & & \\
\hline Part-time & $9(50)$ & 1.87 & $.98-3.57$ & .06 & Part-time & $8(52)$ & 2.99 & $1.64-5.47$ & .00 \\
\hline HEI type & & & & & HEI type & & & & \\
\hline $\begin{array}{l}\text { Russell Group } \\
\text { (reference) }\end{array}$ & $11(66)$ & $*$ & & & $\begin{array}{l}\text { Russell Group } \\
\text { (reference) }\end{array}$ & $8(53)$ & $*$ & & \\
\hline Other & $89(510)$ & 3.34 & $1.46-7.63$ & .00 & Other & $92(593)$ & 1.21 & $.57-2.55$ & .62 \\
\hline Distance & & & & & Distance & & & & \\
\hline $\begin{array}{l}\text { Over } 30 \text { miles } \\
\text { (reference) }\end{array}$ & $62(358)$ & $*$ & & & $\begin{array}{l}\text { Over } 30 \text { miles } \\
\text { (reference) }\end{array}$ & $56(359)$ & & & \\
\hline $\begin{array}{l}\text { Under } 30 \\
\text { miles }\end{array}$ & 38 (218) & 1.73 & $1.14-2.64$ & .01 & $\begin{array}{l}\text { Under } 30 \\
\text { miles }\end{array}$ & $44(287)$ & 1.97 & $1.32-2.93$ & .00 \\
\hline Ethnicity & & & & & Ethnicity & & & & \\
\hline $\begin{array}{l}\text { White } \\
\text { (reference) }\end{array}$ & $72(412)$ & $*$ & & & $\begin{array}{l}\text { White } \\
\text { (reference) }\end{array}$ & $78(503)$ & $*$ & & \\
\hline Black & $9(53)$ & 3.88 & $2.06-7.30$ & .00 & Black & $9(56)$ & .89 & $.45-1.75$ & .72 \\
\hline Asian & $15(88)$ & 5.11 & $3.05-8.57$ & .00 & Asian & $7(46)$ & 1.79 & $.91-3.55$ & .09 \\
\hline Other Mixed & $4(23)$ & 2.76 & $1.10-7.00$ & .03 & Other Mixed & $6(41)$ & 1.08 & $.51-2.30$ & .84 \\
\hline
\end{tabular}

* Reference category

Note: Biological Science: $R^{2}=.26$ (Hosmer \& Lemeshow), .14 (Cox \& Snell), .21 (Nagelkerke). Model $X^{2}(10)=88.96, p<.001$

Note re. Psychology: $R^{2}=.75$ (Hosmer \& Lemeshow), .06 (Cox \& Snell), .10 (Nagelkerke). Model $X^{2}(10)=42.73, p<.001$ 